МИНИСТЕРСТВО НАУКИ И ВЫСШЕГО ОБРАЗОВАНИЯ РОССИЙСКОЙ ФЕДЕРАЦИИ Федеральное государственное автономное образовательное учреждение высшего образования "Казанский (Приволжский) федеральный университет" Институт фрундаментальной медицины и биологии
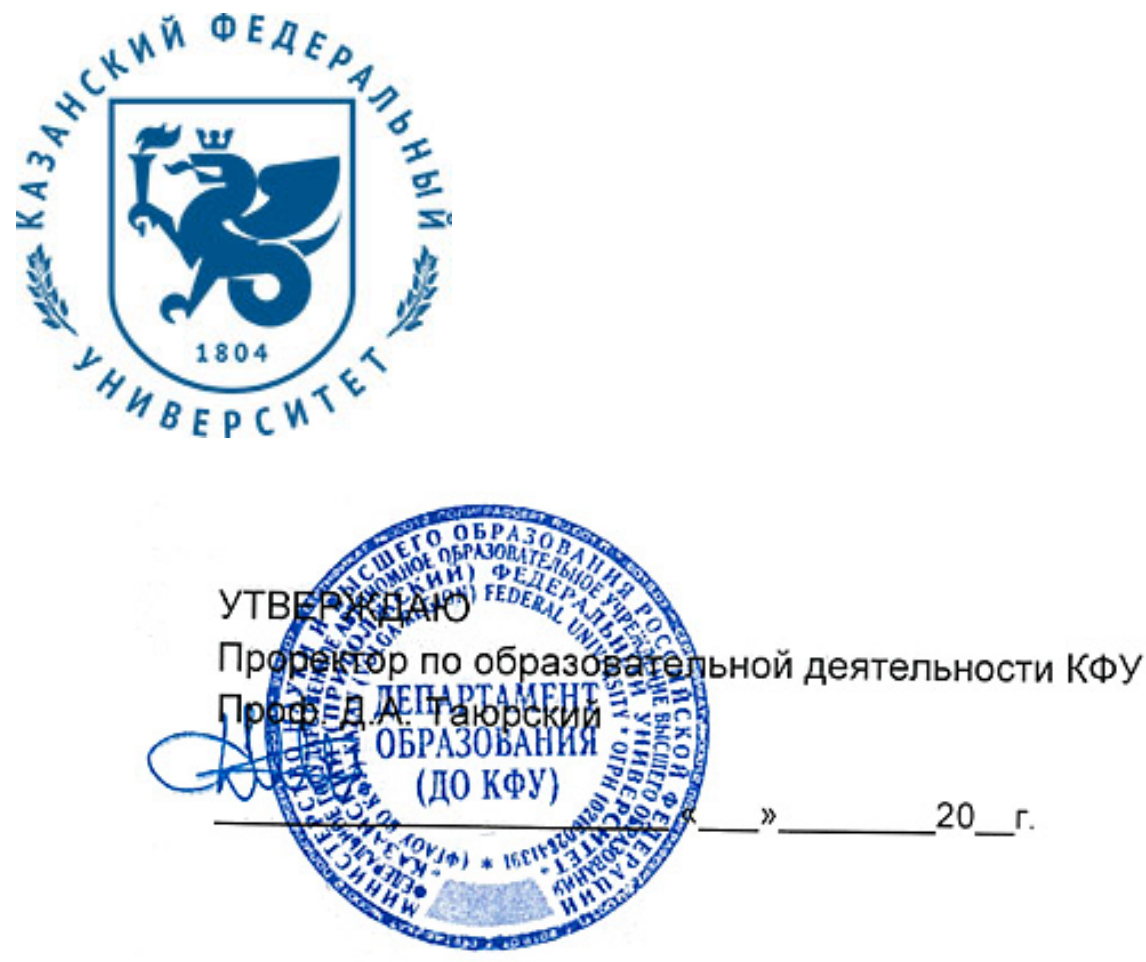

подписано электронно-цифрровой подписью

\title{
Программа дисциплины
}

Иностранный язык

Специальность: 31.05 .03 - Стоматология

Специализация: не предусмотрено

Квалисрикация выпускника: врач - стоматолог

Форма обучения: очное

Язык обучения: русский

Год начала обучения по образовательной программе: $\underline{2018}$ 


\section{Содержание}

1. Перечень планируемых результатов обучения по дисциплине (модулю), соотнесенных с планируемыми результатами освоения ОПОП ВО

2. Место дисциплины (модуля) в структуре ОПОП ВО

3. Объем дисциплины (модуля) в зачетных единицах с указанием количества часов, выделенных на контактную работу обучающихся с преподавателем (по видам учебных занятий) и на самостоятельную работу обучающихся

4. Содержание дисциплины (модуля), структурированное по темам (разделам) с указанием отведенного на них количества академических часов и видов учебных занятий

4.1. Структура и тематический план контактной и самостоятельной работы по дисциплине (модулю)

4.2. Содержание дисциплины (модуля)

5. Перечень учебно-методического обеспечения для самостоятельной работы обучающихся по дисциплине (модулю)

6. Фонд оценочных средств по дисциплине (модулю)

7. Перечень литературы, необходимой для освоения дисциплины (модуля)

8. Перечень ресурсов инорормационно-телекоммуникационной сети "Интернет", необходимых для освоения дисциплины (модуля)

9. Методические указания для обучающихся по освоению дисциплины (модуля)

10. Перечень инсрормационных технологий, используемых при осуществлении образовательного процесса по дисциплине (модулю), включая перечень программного обеспечения и инорормационных справочных систем (при необходимости)

11. Описание материально-технической базы, необходимой для осуществления образовательного процесса по дисциплине (модулю)

12. Средства адаптации преподавания дисциплины (модуля) к потребностям обучающихся инвалидов и лиц с ограниченными возможностями здоровья

13. Приложение №1. Фонд оценочных средств

14. Приложение №2. Перечень литературы, необходимой для освоения дисциплины (модуля)

15. Приложение №3. Перечень инфрормационных технологий, используемых для освоения дисциплины (модуля), включая перечень программного обеспечения и инфрормационных справочных систем 
Программу дисциплины разработал(а)(и) старший преподаватель, б/с Абросимова Г.А. (кафредра иностранных языков, Высшая школа иностранных языков и перевода), GAAbrosimova@kpfu.ru

\section{1. Перечень планируемых результатов обучения по дисциплине (модулю), соотнесенных с планируемыми результатами освоения ОПОП ВО}

Обучающийся, освоивший дисциплину (модуль), должен обладать следующими компетенциями:

\begin{tabular}{|c|c|}
\hline $\begin{array}{l}\text { Шифрр } \\
\text { компетенции }\end{array}$ & $\begin{array}{c}\text { Расшифровка } \\
\text { приобретаемой компетенции }\end{array}$ \\
\hline OK-5 & $\begin{array}{l}\text { готовностью к саморазвитию, самореализации, самообразованию, } \\
\text { использованию творческого потенциала; }\end{array}$ \\
\hline OK-8 & $\begin{array}{l}\text { готовностью к работе в коллективе, толерантно воспринимать социальные, } \\
\text { этнические, конфессиональные и культурные различия }\end{array}$ \\
\hline ОПК-1 & $\begin{array}{l}\text { готовностью решать стандартные задачи профессиональной деятельности с } \\
\text { использованием информационных, библиографических ресурсов, } \\
\text { медико-биологической терминологии, информационно-коммуникационных } \\
\text { технологий и учетом основных требований инфрормационной безопасности; }\end{array}$ \\
\hline ОПК-2 & $\begin{array}{l}\text { готовностью к коммуникации в устной и письменной фрормах на русском и } \\
\text { иностранном языках для решения задач профессиональной деятельности; }\end{array}$ \\
\hline
\end{tabular}

Обучающийся, освоивший дисциплину (модуль):

Должен демонстрировать способность и готовность:

1. должен знать:

- лексический и грамматический минимум общего и профессионального характера; основы перевода с иностранного языка;

2. должен уметь:

- в области аудирования:

воспринимать на слух и понимать основное содержание несложных аутентичных научно- популярных и научных текстов, относящихся к различным типам речи (сообщение, доклад, презентация), а также выделять в них значимую/запрашиваемую инорормацию;

- в области чтения:

понимать основное содержание аутентичных научно- популярных и научных текстов, веб-сайтов; выделять значимую/запрашиваемую информацию из прагматических текстов справочно-инорормационного характера;

- в области говорения:

начинать, вести/поддерживать и заканчивать диалог-расспрос об увиденном, прочитанном, диалог-обмен мнениями и диалог-интервью/ собеседование при приеме на работу, соблюдая нормы речевого этикета, при необходимости используя стратегии восстановления сбоя в процессе коммуникации (переспрос, перефразирование и др.); расспрашивать собеседника, задавать вопросы и отвечать на них, высказывать свое мнение, просьбу, отвечать на предложение собеседника (принятие предложения или отказ); делать сообщения и выстраивать монолог-описание, монолог-повествование и монолог-рассуждение;

-в области письма:

заполнять фрормуляры и бланки прагматического характера; вести запись основных мыслей и фрактов (из аудиотекстов и текстов для чтения), а также запись тезисов устного выступления/ письменного доклада по изучаемой проблематике; поддерживать контакты при помощи электронной почты (писать электронные письма личного характера); оформлять CV/ Resume и сопроводительное письмо, необходимые при приеме на работу, выполнять письменные проектные задания (письменное оформление презентаций, информационных буклетов, рекламных листовок и т.д.);

3. должен владеть:

учебными стратегиями для организации своей учебной деятельности когнитивными стратегиями для автономного изучения иностранного языка стратегиями рефрлексии и самооценки в целях совершенствования личных качеств и достижений презентационными технологиями для предъявления информации.

4. Демонстрировать способность и готовность использовать иностранный язык в ситуациях профрессионального общения. 


\section{2. Место дисциплины (модуля) в структуре ОПОП ВО}

Данная дисциплина (модуль) включена в раздел "Б1.Б.2 Дисциплины (модули)" основной профрессиональной образовательной программы 31.05 .03 "Стоматология (не предусмотрено)" и относится к базовой (общепросрессиональной) части.

Осваивается на 1, 2 курсах в 1, 2, 3 семестрах.

3. Объем дисциплины (модуля) в зачетных единицах с указанием количества часов, выделенных на контактную работу обучающихся с преподавателем (по видам учебных занятий) и на самостоятельную работу обучающихся

Общая трудоемкость дисциплины составляет 10 зачетных(ые) единиц(ы) на 360 часа(ов).

Контактная работа - 216 часа(ов), в том числе лекции - 0 часа(ов), практические занятия - 216 часа(ов), лабораторные работы - 0 часа(ов), контроль самостоятельной работы - 0 часа(ов).

Самостоятельная работа - 135 часа(ов).

Контроль (зачёт / экзамен) - 9 часа(ов).

Форма промежуточного контроля дисциплины: отсутствует в 1 семестре; зачет во 2 семестре; экзамен в 3 семестре.

4. Содержание дисциплины (модуля), структурированное по темам (разделам) с указанием отведенного на них количества академических часов и видов учебных занятий

4.1 Структура и тематический план контактной и самостоятельной работы по дисциплине (модулю)

\begin{tabular}{|c|c|c|c|c|c|c|}
\hline \multirow[t]{2}{*}{$\mathbf{N}$} & \multirow[t]{2}{*}{$\begin{array}{c}\text { Разделы дисциплины / } \\
\text { модуля }\end{array}$} & \multirow[t]{2}{*}{ Семестр } & \multicolumn{3}{|c|}{$\begin{array}{c}\text { Виды и часы } \\
\text { контактной работы, } \\
\text { их трудоемкость } \\
\text { (в часах) }\end{array}$} & \multirow{2}{*}{$\begin{array}{c}\text { Самостоятельная } \\
\text { работа }\end{array}$} \\
\hline & & & Лекции & \begin{tabular}{|c|} 
Практические \\
занятия
\end{tabular} & $\begin{array}{c}\text { Лабораторные } \\
\text { работы }\end{array}$ & \\
\hline 1. & $\begin{array}{l}\text { Тема 1. РАЗВИТИЕ фронетических } \\
\text { навыков }\end{array}$ & 1 & 0 & 3 & 0 & 0 \\
\hline 2. & $\begin{array}{l}\text { Тема 2. РАЗВИТИЕ лексических } \\
\text { навыков }\end{array}$ & 1 & 0 & 9 & 0 & 5 \\
\hline 3. & $\begin{array}{l}\text { Тема 3. РАЗВИТИЕ грамматических } \\
\text { навыков }\end{array}$ & 1 & 0 & 10 & 0 & 5 \\
\hline 4. & \begin{tabular}{|l|} 
Тема 4. РАЗВИТИЕ навыков \\
аудирования
\end{tabular} & 1 & 0 & 10 & 0 & 5 \\
\hline 5. & $\begin{array}{l}\text { Тема 5. РАЗВИТИЕ навыков } \\
\text { говорения }\end{array}$ & 1 & 0 & 10 & 0 & 6 \\
\hline 6. & $\begin{array}{l}\text { Тема 6. РАЗВИТИЕ навыков } \\
\text { коммуникативного чтения }\end{array}$ & 1 & 0 & 10 & 0 & 5 \\
\hline 7. & $\begin{array}{l}\text { Тема 7. РАЗВИТИЕ навыков } \\
\text { коммуникативного письма }\end{array}$ & 1 & 0 & 10 & 0 & 5 \\
\hline 8. & $\begin{array}{l}\text { Тема 8. РАЗВИТИЕ навыков } \\
\text { экстенсивного чтения по } \\
\text { специальности }\end{array}$ & 1 & 0 & 10 & 0 & 5 \\
\hline 9. & $\begin{array}{l}\text { Тема 9. ЗАКРЕПЛЕНИЕ } \\
\text { сронетических навыков }\end{array}$ & 2 & 0 & 3 & 0 & \\
\hline 10. & \begin{tabular}{|l} 
Тема 10. ЗАКРЕПЛЕНИЕ \\
лексических навыков
\end{tabular} & 2 & 0 & 9 & 0 & 5 \\
\hline 11. & $\begin{array}{l}\text { Тема 11. ЗАКРЕПЛЕНИЕ } \\
\text { грамматических навыков }\end{array}$ & 2 & 0 & 10 & 0 & 6 \\
\hline 12. & $\begin{array}{l}\text { Тема 12. ЗАКРЕПЛЕНИЕ навыков } \\
\text { аудирования }\end{array}$ & 2 & 0 & 10 & 0 & 5 \\
\hline 13. & $\begin{array}{l}\text { Тема 13. ЗАКРЕПЛЕНИЕ навыков } \\
\text { говорения }\end{array}$ & 2 & 0 & 10 & 0 & 5 \\
\hline 14. & $\begin{array}{l}\text { Тема 14. ЗАКРЕПЛЕНИЕ навыков } \\
\text { Коммуникативного чтения }\end{array}$ & 2 & 0 & 10 & 0 & 5 \\
\hline & $\begin{array}{l}\text { Тема 15. ЗАКРЕПЛЕНИЕ навыков } \\
\text { Коммуникативного письма }\end{array}$ & 2 & 0 & 10 & 0 & 5 \\
\hline
\end{tabular}




\begin{tabular}{|c|c|c|c|c|c|c|}
\hline \multirow[t]{2}{*}{$\mathbf{N}$} & \multirow[t]{2}{*}{$\begin{array}{c}\text { Разделы дисциплины / } \\
\text { модуля }\end{array}$} & \multirow[t]{2}{*}{ Семестр } & \multicolumn{3}{|c|}{$\begin{array}{c}\text { Виды и часы } \\
\text { контактной работы, } \\
\text { их трудоемкость } \\
\text { (в часах) }\end{array}$} & \multirow{2}{*}{$\begin{array}{c}\text { Самостоятельная } \\
\text { работа }\end{array}$} \\
\hline & & & Лекции & \begin{tabular}{|} 
Практические \\
занятия
\end{tabular} & $\begin{array}{c}\text { Лабораторные } \\
\text { работы }\end{array}$ & \\
\hline 16. & $\begin{array}{l}\text { Тема 16. ЗАКРЕПЛЕНИЕ навыков } \\
\text { экстенсивного чтения по } \\
\text { специальности } \\
\end{array}$ & 2 & 0 & 10 & 0 & 5 \\
\hline 17. & $\begin{array}{l}\text { Тема 17. АВТОМАТИЗАЦИЯ } \\
\text { фронетических навыков }\end{array}$ & 3 & 0 & 3 & 0 & \\
\hline 18. & \begin{tabular}{|l} 
Тема 18. АВТОМАТИЗАЦИЯ \\
лексических навыков
\end{tabular} & 3 & 0 & 7 & 0 & 7 \\
\hline 19. & $\begin{array}{l}\text { Тема 19. АВТОМАТИЗАЦИЯ } \\
\text { навыков коммуникативного } \\
\text { аудирования }\end{array}$ & 3 & 0 & 7 & 0 & 7 \\
\hline 20. & $\begin{array}{l}\text { Тема 20. АВТОМАТИЗАЦИЯ } \\
\text { навыков говорения }\end{array}$ & 3 & 0 & 7 & 0 & 7 \\
\hline 21. & \begin{tabular}{|l} 
Тема 21. АВТОМАТИЗАЦИЯ \\
навыков коммуникативного чтения
\end{tabular} & 3 & 0 & 7 & 0 & 7 \\
\hline 22. & \begin{tabular}{|l} 
Тема 22. АВТОМАТИЗАЦИЯ \\
навыков письма
\end{tabular} & 3 & 0 & 7 & 0 & 7 \\
\hline 23. & $\begin{array}{l}\text { Тема 23. АВТОМАТИЗАЦИЯ } \\
\text { грамматических навыков. Перевод } \\
\text { научно-исследовательских текстов } \\
\text { по специальности с английского } \\
\text { языка на русский }\end{array}$ & 3 & 0 & 10 & 0 & 7 \\
\hline 24. & $\begin{array}{l}\text { Тема 24. АВТОМАТИЗАЦИЯ } \\
\text { навыкОв аудирования по } \\
\text { специальности }\end{array}$ & 3 & 0 & 7 & 0 & 7 \\
\hline 25. & $\begin{array}{l}\text { Тема 25. АВТОМАТИЗАЦИЯ } \\
\text { навыков говорения по } \\
\text { специальности }\end{array}$ & 3 & 0 & 10 & 0 & 7 \\
\hline 26. & $\begin{array}{l}\text { Тема 26. АВТОМАТИЗАЦИЯ } \\
\text { навыков чтения текстов по } \\
\text { специальности } \\
\end{array}$ & 3 & 0 & 7 & 0 & 7 \\
\hline & Итого & & 0 & 216 & 0 & 135 \\
\hline
\end{tabular}

\section{2 Содержание дисциплины (модуля)}

\section{Тема 1. РАЗВИТИЕ фонетических навыков}

особенности артикуляции изучаемого иностранного языка по сравнению с артикуляцией русского языка, система гласных и согласных языка.

\section{Тема 2. РАЗВИТИЕ лексических навыков}

Стилистически нейтральная и стилистически окрашенная наиболее употребительная лексика общего языка в рамках изученных тем. 1. Знакомство. Биографияя. 2. В магазине. 3. Семья, родственные отношения, семейный бюджет. 3. Профессиональная (учебная) деятельность, род занятий. Поиск работы. 4. Распорядок дня; питание, отдых, праздники, занятия спортом, хобби. Наиболее распространенные фрормулы-клише (обращение, приветствие, благодарность, извинение и т.п.). Основные речевые модели для передачи основного содержания текста.

\section{Тема 3. РАЗВИТИЕ грамматических навыков}

Артикль. Общее понятие и основные случаи употребления. Имя существительное.

Образование множественного числа и притяжательного падежа существительного. Имя прилагательное.

Степени сравнения прилагательных. Наречие. Степени сравнения наречий. Имя числительное. Количественные и порядковые числительные. Местоимения: личные, притяжательные, неопределенные, вопросительные, относительные, указательные. Наиболее употребительные предлоги. Наиболее употребительные сочинительные и подчинительные союзы.

Тема 4. РАЗВИТИЕ навыков аудирования 
Фонологическое, лексическое, грамматическое аудирование. Коммуникативное аудирование материалов СРЕДНЕЙ СТЕПЕНИ СЛОЖНОСТИ в зависимости от уровня владения языком: -понимание общего содержания прослушанной информации -детальное понимание прослушанного, -восстановление полного текста в письменном виде при многократном прослушивании -вычленение и понимание определенной инорормации, ограниченной коммуникативным заданием -умение, помимо адекватного восприятия и осмысления сообщения, понимать намерения, установки, переживания, состояния и пр. говорящего.

\section{Тема 5. РАЗВИТИЕ навыков говорения}

Монологическое высказывание в соответствии с предложенной ситуацией и ролью, навыки условно-неподготовленной и неподготовленной речи, дискуссия,беседа, расспрос - объяснение по пройденной тематике, проблемные беседы (отбор и оценивание характеристик в соответствии с собственной точкой зрения, выражение согласия/несогласия, аргументация) с правильным использованием фрормул речевого этикета и отбором соответствующих языковых средств для выполнения определенного коммуникативного задания. Коммуникация должна быть эфрфективной, т. е. цели должны быть достигнуты, при возникающих трудностях коммуникация должна быть восстановлена. Тематика текстов и ситуаций общения: 1. Знакомство. Биография. 2. В магазине. 3. Семья, родственные отношения, семейный бюджет. 3. Профрессиональная (учебная ) деятельность, род занятий. Поиск работы. 4. Распорядок дня; питание, отдых, праздники, занятия спортом, хобби. Языковая функциональность: -рекомендация, совет, собственное мнение; - согласие, отказ;- приглашение, отказ от приглашения

\section{Тема 6. РАЗВИТИЕ навыков коммуникативного чтения}

изучающее, ознакомительное, просмотровое, аналитическое чтение текстов СРЕДНЕЙ СТЕПЕНИ СЛОЖНОСТИ в зависимости от уровня владения языком из общественно-политической, социально-культурной и учебно-профрессиональной сорер Типы текста: микротекст, макротекст, диалогическое/монологическое единство, письменный/устный текст. Структурная, смысловая и коммуникативная целостность текста. Организация текста в соответствии с коммуникативной целью высказывания. Соотношение простых и сложных предложений в тексте, определяемое его коммуникативной функцией.

\section{Тема 7. РАЗВИТИЕ навыков коммуникативного письма}

Стратегия порождения письменных сообщений: - планирование - компенсация - мониторинг

\section{Тема 8. РАЗВИТИЕ навыков экстенсивного чтения по специальности}

Дальнейшее расширение словарного запаса за счет освоения и использования научной терминологии по специальности в соответствующем контексте. Просмотровое и поисковое чтение текстов по специальности среднего уровня сложности с последующим заданием на говорение. Тематика текстов по специальности: huтап body, study of anatomy, muscles, organs,veins and arteries.

\section{Тема 9. ЗАКРЕПЛЕНИЕ фонетических навыков}

ритмика (ударные и неударные слова в потоке речи); паузация: деление речевого потока на смысловые группы нейтральная интонация повествования и вопроса.

\section{Тема 10. ЗАКРЕПЛЕНИЕ лексических навыков}

Стилистически нейтральная и стилистически окрашенная наиболее употребительная лексика общего языка в рамках изученных тем. 1. Описание жилища, работа по дому. Поиск жилья. 2. Времена года; погода. 3. Туризм. Путешествие различными видами транспорта. 4. Географрическое положение стран, описание городов. Знакомство с основными типами словарей (двуязычными и одноязычными толковыми, фрразеологическими, терминологическими и т. д.). Полисемия. Синонимия. Антонимия.

\section{Тема 11. ЗАКРЕПЛЕНИЕ грамматических навыков}

Глагол. Личные формы глагола. Употребление глаголов have, be, do, should, would, shall will. Модальные глаголы. Phrasal verbs. Видовременные фрормы глагола в активном и пассивном залоге. Порядок слов в простом предложении (повествовательном, вопросительном, отрицательном). Сложное предложение. Типы придаточных предложений (изъяснительное, определительное, обстоятельственное времени, образа действия, места, цели, причины и т.д.). Косвенная речь.

\section{Тема 12. ЗАКРЕПЛЕНИЕ навыков аудирования}

Фонологическое, лексическое, грамматическое аудирование. Коммуникативное аудирование материалов ПОВЫШЕННОЙ СТЕПЕНИ СЛОЖНОСТИ в зависимости от уровня владения языком: -понимание общего содержания прослушанной информации -детальное понимание прослушанного, -восстановление полного текста в письменном виде при многократном прослушивании -вычленение и понимание определенной инорормации, ограниченной коммуникативным заданием -умение, помимо адекватного восприятия и осмысления сообщения, понимать намерения, установки, переживания, состояния и пр. говорящего.

\section{Тема 13. ЗАКРЕПЛЕНИЕ навыков говорения}

Монологическое высказывание в соответствии с предложенной ситуацией и ролью, навыки условно-неподготовленной и неподготовленной речи, дискуссия, беседа, расспрос - объяснение по пройденной тематике, проблемные беседы (отбор и оценивание характеристик в соответствии с собственной точкой зрения, выражение согласия/несогласия, аргументация) с правильным использованием фрормул речевого этикета и отбором соответствующих языковых средств для выполнения определенного коммуникативного задания. Коммуникация должна быть эфрфективной, т. е. цели должны быть достигнуты, при возникающих трудностях коммуникация должна быть восстановлена. Тематика текстов и ситуаций общения: 1. 
Описание жилища, работа по дому. Поиск жилья. 2. Времена года; погода. 3. Туризм. Путешествие различными видами транспорта. 4. Географическое положение стран, описание городов. Языковая функциональность: телефонные переговоры;- критические замечания;- описание, анализ, объяснение.

\section{Тема 14. ЗАКРЕПЛЕНИЕ навыков коммуникативного чтения}

Способность понимать и извлекать инорормацию из текстов): изучающее, ознакомительное, просмотровое, аналитическое чтение текстов ПОВЫШЕННОЙ СТЕПЕНИ СЛОЖНОСТИ в зависимости от уровня владения языком из общественно-политической, социально-культурной и учебно-профессиональной сфер Типы текста: микротекст, макротекст, диалогическое/монологическое единство, письменный/устный текст. Структурная, смысловая и коммуникативная целостность текста. Организация текста в соответствии с коммуникативной целью высказывания. Соотношение простых и сложных предложений в тексте, определяемое его коммуникативной фрункцией.

\section{Тема 15. ЗАКРЕПЛЕНИЕ навыков коммуникативного письма}

Формы письменного сообщения: официальное и неофициальное письмо, CV, план, конспект, резюме текста, изложение его содержания с критической оценкой, реферирование и аннотирование.

\section{Тема 16. ЗАКРЕПЛЕНИЕ навыков экстенсивного чтения по специальности}

Расширение словарного запаса за счет освоения и использования научной терминологии по специальности в соответствующем контексте. Просмотровое и поисковое чтение текстов повышенного уровня сложности по специальности сложности с последующим заданием на говорение, а именно, презентацией материала по заданной теме, грамотным составлением аннотации, резюме или рефрерата по тексту. примерные темы текстов для чтения: molecular biology, inheritance, coordinations

\section{Тема 17. АВТОМАТИЗАЦИЯ фонетических навыков}

Умение читать знакомые и незнакомые тексты вслух, бегло, с правильной интонацией и распределением пауз; -установка и корректировка тех звуков, неправильное произнесение которых ведет к искажению смысла

\section{Тема 18. АВТОМАТИЗАЦИЯ лексических навыков}

Стилистически нейтральная и стилистически окрашенная наиболее употребительная лексика общего языка в рамках изученных тем. 1. Предметы в быту. Еда. 2. Внешность, характер, поведение и привычки, чувства людей. 3.Мечты, планы, амбиции. 4. Искусство (кино, театр, живопись). Активное использование основных типов словарей (двуязычными и одноязычными толковыми, фрразеологическими, терминологическими и т. д. ).Полисемия. Синонимия. Антонимия. Основные термины широкой специальности. Знакомство с терминологическими словарями и справочниками. Знакомство с общенаучной лексикой, устойчивые словосочетания, свойственные научному стилю общения

\section{Тема 19. АВТОМАТИЗАЦИЯ навыков коммуникативного аудирования}

Фонологическое, лексическое, грамматическое аудирование. Коммуникативное аудирование материалов ВЫСОКОЙ СТЕПЕНИ СЛОЖНОСТИ в зависимости от уровня владения языком: -понимание общего содержания прослушанной информации -детальное понимание прослушанного, -восстановление полного текста в письменном виде при многократном прослушивании -вычленение и понимание определенной иноормации, ограниченной коммуникативным заданием -умение, помимо адекватного восприятия и осмысления сообщения, понимать намерения, установки, переживания, состояния и пр. говорящего.

\section{Тема 20. АВТОМАТИЗАЦИЯ навыков говорения}

Монологическое высказывание в соответствии с предложенной ситуацией и ролью, навыки условно-неподготовленной и неподготовленной речи, дискуссия,беседа, расспрос - объяснение по пройденной тематике, проблемные беседы (отбор и оценивание характеристик в соответствии с собственной точкой зрения, выражение согласия/несогласия, аргументация) с правильным использованием фрормул речевого этикета и отбором соответствующих языковых средств для выполнения определенного коммуникативного задания. Коммуникация должна быть эфрфективной, т. е. цели должны быть достигнуты, при возникающих трудностях коммуникация должна быть восстановлена. Тематика текстов и ситуаций общения: 9. Предметы в быту. Еда. 10. Внешность, характер, поведение и привычки, чувства людей. 11.Мечты, планы, амбиции. 12. Искусство (кино, театр, живопись). Языковая фрункциональность:- фрормулирование гипотезы;- убеждение

\section{Тема 21. АВТОМАТИЗАЦИЯ навыков коммуникативного чтения}

изучающее, ознакомительное, просмотровое, аналитическое чтение текстов ВЫСОКОЙ СТЕПЕНИ СЛОЖНОСТИ в зависимости от уровня владения языком из общественно-политической, социально-культурной и учебно-профессиональной сфер Типы текста: микротекст, макротекст, диалогическое/монологическое единство, письменный/устный текст. Структурная, смысловая и коммуникативная целостность текста. Организация текста в соответствии с коммуникативной целью высказывания. Соотношение простых и сложных предложений в тексте, определяемое его коммуникативной функцией.

\section{Тема 22. АВТОМАТИЗАЦИЯ навыков письма}

Основы академического письма. Совершенствование умения продуцировать письменное изложение разных видов: доклад, рефрерат-резюме, реферат-обзор, сочинение-рассуждение, аннотацию и др. в пределах научной тематики. Особое внимание уделяется развитию умения логического построения письменного сообщения, умению выбора адекватных языковых средств.

Тема 23. АВТОМАТИЗАЦИЯ грамматических навыков. Перевод научно-исследовательских текстов по специальности с английского языка на русский 
Грамматические трудности, свойственные письменной научной речи: Пассивный залог. Инговые фрормы (сравнительный анализ) и сложные конструкции на их основе. Способы их перевода. Типы текста: микротекст, макротекст, диалогическое/монологическое единство, письменный/устный текст. Структурная, смысловая и коммуникативная целостность текста. Организация текста в соответствии с коммуникативной целью высказывания. Соотношение простых и сложных предложений в тексте, определяемое его коммуникативной функцией. Специфрика научного функционального стиля. Проблема адекватности перевода. Полная и неполная адекватность. Тема и рема. Лингвистические и экстралингвистические трудности перевода. Предпереводческий анализ текста. Переводческие трансорормации

\section{Тема 24. АВТОМАТИЗАЦИЯ навыков аудирования по специальности}

понимание диалогической и монологической речи в сфере профессиональной и научной коммуникации; тренировка восприятия на слух профессионально ориентированных аудиотекстов (доклады, научные дискуссии, презентации, отрывки лекций и пр.) с последующим их обсуждением. примерные темы для аудирования: medicine, history of medicine

\section{Тема 25. АВТОМАТИЗАЦИЯ навыков говорения по специальности}

умение пользоваться речевыми средствами убеждения в кратком публичном выступлении в непосредственном контакте с аудиторией, - устное реферирование научного текста, - основы публичной речи (доклад, презентация, и пр.). примерные темы для говорения: diseases of human organism, treatment of diseases

\section{Тема 26. АВТОМАТИЗАЦИЯ навыков чтения текстов по специальности}

Дальнейшее расширение словарного запаса за счет освоения и использования научной терминологии по специальности в соответствующем контексте. Чтение текстов по специальности соответствующего уровня сложности с последующим заданием на говорение, а именно, презентацией материала по заданной теме, грамотным составлением аннотации, резюме или реферата по тексту, подготовкой научного доклада. примерные тексты для чтения:"new diseases", "new trends in medicine"

\section{5. Перечень учебно-методического обеспечения для самостоятельной работы обучающихся по дисциплине (модулю)}

Самостоятельная работа обучающихся выполняется по заданию и при методическом руководстве преподавателя, но без его непосредственного участия. Самостоятельная работа подразделяется на самостоятельную работу на аудиторных занятиях и на внеаудиторную самостоятельную работу. Самостоятельная работа обучающихся включает как полностью самостоятельное освоение отдельных тем (разделов) дисциплины, так и проработку тем (разделов), осваиваемых во время аудиторной работы. Во время самостоятельной работы обучающиеся читают и конспектируют учебную, научную и справочную литературу, выполняют задания, направленные на закрепление знаний и отработку умений и навыков, готовятся к текущему и промежуточному контролю по дисциплине.

Организация самостоятельной работы обучающихся регламентируется нормативными документами, учебно-методической литературой и электронными образовательными ресурсами, включая:

Порядок организации и осуществления образовательной деятельности по образовательным программам высшего образования - программам бакалавриата, программам специалитета, программам магистратуры (утвержден приказом Министерства образования и науки Российской Федерации от 5 апреля 2017 года №301)

Письмо Министерства образования Российской Федерации №14-55-996ин/15 от 27 ноября 2002 г. "Об активизации самостоятельной работы студентов высших учебных заведений"

Устав фредерального государственного автономного образовательного учреждения "Казанский (Приволжский) фредеральный университет"

Правила внутреннего распорядка фредерального государственного автономного образовательного учреждения высшего профессионального образования "Казанский (Приволжский) федеральный университет"

Локальные нормативные акты Казанского (Приволжского) фредерального университета

Иностранный Язык. Refresh Your Grammar. Part I - https://edu.kpfu.ru/course/view.php?id=1607

\section{6. Фонд оценочных средств по дисциплине (модулю)}

Фонд оценочных средств по дисциплине (модулю) включает оценочные материалы, направленные на проверку освоения компетенций, в том числе знаний, умений и навыков. Фонд оценочных средств включает оценочные средства текущего контроля и оценочные средства промежуточной аттестации.

В фронде оценочных средств содержится следующая информация:

- соответствие компетенций планируемым результатам обучения по дисциплине (модулю);

- критерии оценивания сорормированности компетенций;

- механизм фрормирования оценки по дисциплине (модулю);

- описание порядка применения и процедуры оценивания для каждого оценочного средства;

- критерии оценивания для каждого оценочного средства;

- содержание оценочных средств, включая требования, предъявляемые к действиям обучающихся, демонстрируемым результатам, задания различных типов.

Фонд оценочных средств по дисциплине находится в Приложении 1 к программе дисциплины (модулю). 


\section{7. Перечень литературы, необходимой для освоения дисциплины (модуля)}

Освоение дисциплины (модуля) предполагает изучение основной и дополнительной учебной литературы. Литература может быть доступна обучающимся в одном из двух вариантов (либо в обоих из них):

- в электронном виде - через электронные библиотечные системы на основании заключенных КФУ договоров с правообладателями;

- в печатном виде - в Научной библиотеке им. Н.И. Лобачевского. Обучающиеся получают учебную литературу на абонементе по читательским билетам в соответствии с правилами пользования Научной библиотекой.

Электронные издания доступны дистанционно из любой точки при введении обучающимся своего логина и пароля от личного кабинета в системе "Электронный университет". При использовании печатных изданий библиотечный фонд должен быть укомплектован ими из расчета не менее 0,5 экземпляра (для обучающихся по ФГОС 3++ - не менее 0,25 экземпляра) каждого из изданий основной литературы и не менее 0,25 экземпляра дополнительной литературы на каждого обучающегося из числа лиц, одновременно осваивающих данную дисциплину.

Перечень основной и дополнительной учебной литературы, необходимой для освоения дисциплины (модуля), находится в Приложении 2 к рабочей программе дисциплины. Он подлежит обновлению при изменении условий договоров КФУ с правообладателями электронных изданий и при изменении комплектования фрондов Научной библиотеки КФУ.

\section{8. Перечень ресурсов информационно-телекоммуникационной сети "Интернет", необходимых для освоения дисциплины (модуля)}

American scientific - http://www.scientificamerican.com/

Free Medical Journals - http://www.freemedicaljournals.com/

Science.com - http://www.sciencemag.org/

\section{9. Методические указания для обучающихся по освоению дисциплины (модуля)}

\begin{tabular}{|c|c|}
\hline Вид работ & Методические рекомендации \\
\hline $\begin{array}{c}\text { практические } \\
\text { занятия }\end{array}$ & $\begin{array}{l}\text { В ходе занятий студенты должны: } \\
\text { - вести конспектирование учебного материала; } \\
\text { - обращать особое внимание на категории, фрормулировки, раскрывающие содержание тех или } \\
\text { иных явлений и процессов, научные выводы и практические рекомендации; } \\
\text { - задавать преподавателю уточняющие вопросы с целью уяснения теоретических положений, } \\
\text { разрешения } \\
\text { спорных ситуаций. }\end{array}$ \\
\hline $\begin{array}{c}\text { самостоя- } \\
\text { тельная } \\
\text { работа }\end{array}$ & $\begin{array}{l}\text { Студент обязан в полном объѐме использовать время самостоятельной работы, } \\
\text { предусмотренное настоящей рабочей программой, для изучения соответствующих разделов } \\
\text { дисциплины, и своевременно обращаться к преподавателю в случае возникновения } \\
\text { затруднений при выполнении заданий в рамках самостоятельной работы. } \\
\text { Прорабатывая материал во время самостоятельной работы, студент обязан отметить в } \\
\text { конспекте утверждения, определения, выводы, смысл или обоснованность которых ему } \\
\text { непонятны, и обратиться к рекомендуемой литературе за разъяснениями. Если рекомендуемая } \\
\text { литература не содержит требуемых объяснений, необходимо обратиться к преподавателю с } \\
\text { вопросом на практическом занятии или во время, выделенное для индивидуальных } \\
\text { консультаций. }\end{array}$ \\
\hline зачет & $\begin{array}{l}\text { При подготовке к зачету студентам необходимо: } \\
\text { - повторять пройденный материал в строгом соответствии с учебной программой, примерным } \\
\text { перечнем вопросом, выносимых на зачет, содержащихся в данной программе; } \\
\text { - использовать конспект занятий и литературу, рекомендованную преподавателем; } \\
\text { - обращать особое внимание на темы учебных занятий, по разным причинам пропущенных } \\
\text { студентом; при необходимости обращаться за консультацией и методической помощью к } \\
\text { преподавателю. } \\
\text { - изучить вопросы для зачета, представленные преподавателем }\end{array}$ \\
\hline
\end{tabular}




\begin{tabular}{|c|l|}
\hline Вид работ & \multicolumn{1}{|c|}{ Методические рекомендации } \\
\hline экзамен & При подготовке к экзамену студентам необходимо: \\
& - повторять пройденный материал в строгом соответствии с учебной программой, примерным \\
& перечнем вопросом, выносимых на экзамен, содержащихся в данной программе; \\
& - использовать конспект занятий и литературу, рекомендованную преподавателем; \\
& - обращать особое внимание на темы учебных занятий, по разным причинам пропущенных \\
& студентом; при необходимости обращаться за консультацией и методической помощью к \\
& преподавателю. \\
& - изучить вопросы для экзамена, представленные преподавателем \\
\hline
\end{tabular}

10. Перечень инфрормационных технологий, используемых при осуществлении образовательного процесса по дисциплине (модулю), включая перечень программного обеспечения и информационных справочных систем (при необходимости)

Перечень информационных технологий, используемых при осуществлении образовательного процесса по дисциплине (модулю), включая перечень программного обеспечения и инорормационных справочных систем, представлен в Приложении 3 к рабочей программе дисциплины (модуля).

\section{1. Описание материально-технической базы, необходимой для осуществления образовательного процесса по дисциплине (модулю)}

Материально-техническое обеспечение образовательного процесса по дисциплине (модулю) включает в себя следующие компоненты:

Помещения для самостоятельной работы обучающихся, укомплектованные специализированной мебелью (столы и стулья) и оснащенные компьютерной техникой с возможностью подключения к сети "Интернет" и обеспечением доступа в электронную инфрормационно-образовательную среду КФУ.

Учебные аудитории для контактной работы с преподавателем, укомплектованные специализированной мебелью (столы и стулья).

Компьютер и принтер для распечатки раздаточных материалов.

Мультимедийная аудитория.

Компьютерный класс.

Лингафонный кабинет.

\section{2. Средства адаптации преподавания дисциплины к потребностям обучающихся инвалидов и лиц с ограниченными возможностями здоровья}

При необходимости в образовательном процессе применяются следующие методы и технологии, облегчающие восприятие информации обучающимися инвалидами и лицами с ограниченными возможностями здоровья:

- создание текстовой версии любого нетекстового контента для его возможного преобразования в

альтернативные формы, удобные для различных пользователей;

- создание контента, который можно представить в различных видах без потери данных или структуры, предусмотреть возможность масштабирования текста и изображений без потери качества, предусмотреть доступность управления контентом с клавиатуры;

- создание возможностей для обучающихся воспринимать одну и ту же инорормацию из разных источников например, так, чтобы лица с нарушениями слуха получали инфрормацию визуально, с нарушениями зрения аудиально;

- применение программных средств, обеспечивающих возможность освоения навыков и умений, фрормируемых дисциплиной, за счёт альтернативных способов, в том числе виртуальных лабораторий и симуляционных технологий;

- применение дистанционных образовательных технологий для передачи информации, организации различных фрорм интерактивной контактной работы обучающегося с преподавателем, в том числе вебинаров, которые могут быть использованы для проведения виртуальных лекций с возможностью взаимодействия всех участников дистанционного обучения, проведения семинаров, выступления с докладами и защиты выполненных работ, проведения тренингов, организации коллективной работы;

- применение дистанционных образовательных технологий для организации орорм текущего и промежуточного контроля;

- увеличение продолжительности сдачи обучающимся инвалидом или лицом с ограниченными возможностями здоровья фрорм промежуточной аттестации по отношению к установленной продолжительности их сдачи:

- продолжительности сдачи зачёта или экзамена, проводимого в письменной фрорме, - не более чем на 90 минут; - продолжительности подготовки обучающегося к ответу на зачёте или экзамене, проводимом в устной фрорме, - не более чем на 20 минут;

- продолжительности выступления обучающегося при защите курсовой работы - не более чем на 15 минут. 
Программа составлена в соответствии с требованиями ФГОС ВО и учебным планом по специальности: 31.05 .03 "Стоматология" и специализации "не предусмотрено". 
Перечень литературы, необходимой для освоения дисциплины (модуля)

Специальность: 31.05 .03 - Стоматология

Специализация: не предусмотрено

Квалисрикация выпускника: врач - стоматолог

Форма обучения: очное

Язык обучения: русский

Год начала обучения по образовательной программе: 2018

Основная литература:

1. Марковина И.Ю., Английский язык : учебник / Марковина И.Ю., Максимова З.К., Вайнштейн М.В.; Под общей ред. И.Ю. Марковиной. - 4-е изд., испр. и перераб. - М. : ГЭОТАР-Медиа, 2013. - 368 с. - ISBN 978-5-9704-2379-0 Текст : электронный // ЭБС 'Консультант студента' : [сайт]. - URL :

http://www.studentlibrary.ru/book/ISBN9785970423790.html (дата обращения: 28.04.2020). - Режим доступа : по подписке.

2. Марковина И.Ю., Английский язык. Грамматический практикум для медиков. Часть 1. Употребление личных фоорм глагола в научном тексте. Рабочая тетрадь : учебное пособие / Марковина И.Ю., Громова Г.Е. - М. : ГЭОТАР-Медиа, 2013. - 200 с. - ISBN 978-5-9704-2373-8 - Текст : электронный // ЭБС 'Консультант студента' : [сайт]. - URL : https://www.studentlibrary.ru/book/ISBN9785970423738.html (дата обращения: 28.04.2020). - Режим доступа : по подписке.

3. Маслова А.М., Английский язык для медицинских вузов / Маслова А. М., Вайнштейн З. И., Плебейская Л. С. - М. : ГЭОТАР-Медиа, 2014. - 336 с. - ISBN 978-5-9704-2828-3 - Текст : электронный // ЭБС 'Консультант студента' : [сайт]. - URL : http://www.studentlibrary.ru/book/ISBN9785970428283.html (дата обращения: 28.04.2020). - Режим доступа : по подписке.

\section{Дополнительная литература:}

1. Берзегова Л.Ю., Английский язык. English in Dentistry : учебник / Под ред. Л.Ю. Берзеговой. - 2-е изд., испр. и доп. - М. : ГЭОТАР-Медиа, 2013. - 360 с. - ISBN 978-5-9704-2435-3 - Текст : электронный // ЭБС 'Консультант студента' : [сайт]. - URL : http://www.studentlibrary.ru/book/ISBN9785970424353.html (дата обращения: 28.04.2020). Режим доступа: по подписке.

2. Levchuk I.P., First Aid in Case of Accidents and Emergency Situations : Preparation Questions for a Modular Assessment / Levchuk I.P., Kostyuchenko M.V. - М. : ГЭОТАР-Медиа, 2015. - 32 с. - ISBN 978-5-9704-3450-5 - Текст : электронный // ЭБС 'Консультант студента' : [сайт]. - URL :

http://www.studentlibrary.ru/book/ISBN9785970434505.html (дата обращения: 28.04.2020). - Режим доступа : по подписке.

3. Билич Г.Л., Анатомия человека / Билич Г.Л., Крыжановский В.А. - М. : ГЭОТАР-Медиа, 2013. - 560 с. - ISBN 978-5-9704-2447-6 - Текст : электронный // ЭБС 'Консультант студента' : [сайт]. - URL : http://www.studentlibrary.ru/book/ISBN9785970424476.html (дата обращения: 28.04.2020). - Режим доступа : по подписке. 
Приложение 3

к рабочей программе дисциплины (модуля)

Б1.Б.2 Иностранный язык

Перечень информационных технологий, используемых для освоения дисциплины (модуля), включая перечень программного обеспечения и информационных справочных систем

Специальность: 31.05 .03 - Стоматология

Специализация: не предусмотрено

Квалисрикация выпускника: врач - стоматолог

Форма обучения: очное

Язык обучения: русский

Год начала обучения по образовательной программе: $\underline{2018}$

Освоение дисциплины (модуля) предполагает использование следующего программного обеспечения и инорормационно-справочных систем:

Операционная система Microsoft Windows 7 Профрессиональная или Windows XP (Volume License)

Пакет офрисного программного обеспечения Microsoft Office 365 или Microsoft Office Professional plus 2010

Браузер Mozilla Firefox

Браузер Google Chrome

Adobe Reader XI или Adobe Acrobat Reader DC

Kaspersky Endpoint Security для Windows

Учебно-методическая литература для данной дисциплины имеется в наличии в электронно-библиотечной системе "Консультант студента", доступ к которой предоставлен обучающимся. Многопрофрильный образовательный ресурс "Консультант студента" является электронной библиотечной системой (ЭБС), предоставляющей доступ через сеть Интернет к учебной литературе и дополнительным материалам, приобретенным на основании прямых договоров с правообладателями. Полностью соответствует требованиям фредеральных государственных образовательных стандартов высшего образования к комплектованию библиотек, в том числе электронных, в части фрормирования фрондов основной и дополнительной литературы. 